\title{
ROTAÇÃO ANTI-HORÁRIA DO PLANO OCLUSAL NO TRATAMENTO DE PACIENTES ORTODÔNTICO-CIRÚRGICO
}

Rafael SANTOS, Delson COSTA, Nelson Barbosa REBELATTO, Paulo MÜLLER

O reconhecimento da beleza facial é uma característica nata dos olhos humanos. Entretanto, a definição objetiva dos componentes da beleza é extremamente difícil. À primeira vista o planejamento facial recomendado pode parecer complexo, mas nunca se deve esquecer que o rosto humano é complexo também, e, conseqüentemente, este tipo de análise completa permite a redução dos erros no tratamento ortodôntico-cirúrgico. (Willian Arnnet, 2004). O presente trabalho tem o objetivo de relatar um caso clínico de um paciente que se submeteu a cirurgia ortognática onde no planejamento cirúrgico ocorreu a rotação do plano oclusal, no sentido anti-horário, com a finalidade de melhor posicionamento das estruturas maxilares, vias aéreas e posicionamento do mento. Trata-se de um conceito da mais alta relevância para os Ortodontista e Cirurgiões Buco-Maxilos-Faciais cujo objetivo principal é maximizar o equilíbrio e Harmonia facial.

Palavras-chaves: Cirurgia; Osteotomia; Harmonia. 